ISSN: 2302-8556

\title{
Pengaruh Sanksi Perpajakan, Penggunaan E-Spt, Dan Kualitas Pelayanan Fiskus Pada Kepatuhan Wajib Pajak Orang Pribadi
}

\author{
I Gede Adhi Adnyana ${ }^{1}$ \\ I Ketut Jati ${ }^{2}$ \\ ${ }^{1}$ Fakultas Ekonomi dan Bisnis Universitas Udayana (Unud), Bali, Indonesia \\ email: adhiadnyana@yahoo.com / Telp: 087865478255 \\ ${ }^{2}$ Fakultas Ekonomi dan Bisnis Universitas Udayana (Unud), Bali, Indonesia
}

\begin{abstract}
ABSTRAK
Penelitian ini bertujuan untuk mengetahui Pengaruh sanksi perpajakan, penggunaan eSPT, dan kualitas pelayanan fiskus pada kepatuhan wajib pajak orang pribadi yang terdaftar di Kantor Pelayanan Pajak Pratama Gianyar. Metode analisis data yang digunakan adalah regresi linear berganda. Jenis penelitian ini merupakan penelitian dengan data primer yang diperoleh dari jawaban wajib pajak orang pribadi yang terdaftar di KPP Pratama Gianyar, yaitu jawaban terhadap serangkaian pertanyaan dari kuesioner yang diajukan oleh peneliti mengenai faktor-faktor yang memengaruhi kepatuhan wajib pajak. Sampel ditentukan menggunakan nonprobability sampling dengan teknik accidental sampling. Hasil penelitian ini menunjukkan bahwa sanksi perpajakan, penggunaan e-SPT, dan kualitas pelayanan fiskus berpengaruh positif terhadap kepatuhan Wajib Pajak orang pribadi yang terdaftar di Kantor Pelayanan Pajak Pratama Gianyar.

Kata Kunci: sanksi perpajakan, penggunaan e-spt, kualitas pelayanan fiskus,kepatuhan wajib pajak orang pribadi
\end{abstract}

\begin{abstract}
This study aims to determine the effect of taxation sanctions, the use of e-SPT, and the service quality of tax authorities on individual taxpayer compliance registered at the Gianyar Primary Tax Service Office. Data analysis method used is multiple linear regression. This type of research is a study with primary data obtained from the answers of individual taxpayers who are registered in the Gianyar Primary Tax Office, which is the answer to a series of questions from the questionnaire submitted by researchers regarding factors that influence taxpayer compliance. The sample was determined using nonprobability sampling with accidental sampling technique. The results of this study indicate that tax sanctions, the use of e-SPT, and the quality of service of tax authorities have a positive effect on individual taxpayer compliance registered at the Gianyar Primary Tax Service Office.

Keywords: taxation sanctions, use of e-spt, quality of fiscal services, personal taxpayer compliance.
\end{abstract}

\section{PENDAHULUAN}

Salah satu sumber pendapatan tertinggi dan terpenting bagi suatu negara berasal dari pajak yang ditetapkan. Rustiyaningsih (2011) menyatakan bahwa pertumbuhan ekonomi sangat memengaruhi pajak dimana bila pertumbuhan ekonomi meningkat, maka pendapatan masyarakat turut meningkat yang berdampak pada kemampuan 
mereka dalam membayar pajak. Pajak yang diterapkan pemerintah juga memiliki tujuan-tujuan yang jelas yang berkaitan dengan pembangunan infrastruktur, sumber daya manusia, dan lainnya yang mendukung pertumbuhan ekonomi. Selain itu menurut Nurkse (1971) dalam Muchlis (2002), pajak juga berfungsi untuk membatasi konsumsi masyarakat, memeratakan keadilan sosial kepada masyarakat melalui, dan untuk investasi pemerintah melalui APBN. Namun tentunya banyak masyarakat menganggap bahwa pajak hanya menjadi beban karena mengurangi penghasilan mereka. Hal ini mengakibatkan banyak masyarakat atau pun badan yang melakukan praktik-praktik legal atau pun ilegal untuk mengurangi pembayaran pajak. Bahkan saat ini banyak yang mengendapkan atau menyimpan kekayaan yang dimiliki di luar negeri atau di negara-negara yang termasuk dalam Tax Haven yang memiliki tarif pajak yang rendah. Hal ini pula yang mendorong pemerintah untuk melakukan program Tax Amnesty atau pengampunan pajak untuk menarik kembali uang-uang yang disimpan di luar negeri kembali ke Indonesia. Peserta tax amnesty sebanyak 974.000 wajib pajak dengan pelaporan harta mencapai Rp4.750 Triliun. Capaian ini juga menunjukkan bahwa wajib pajak di Indonesia masih banyak yang belum mengungkapkan harta kekayaan atau pun pendapatannya secara riil sehingga kepatuhan wajib pajak di Indonesia juga perlu ditingkatkan (Sri Mulyani, siaran pers, 31 Maret 2017).

Pendapatan perpajakan yang dilakukan oleh Direktorat Jenderal Pajak (DJP) lebih mudah untuk dilakukan dan didata melalui adanya reformasi perpajakan jilid pertama pada tahun 1983-2009 dengan melakukan modernisasi perpajakan terkait intensifikasi dan ekstensifikasi perpajakan. Pada reformasi jilid 
dua ini juga mencakup dalam penggunaan aplikasi e-SPT dalam melaporkan SPT tahunan. Modernisasi yang terjadi di daerah-daerah di belahan dunia terjadi pertama kali di daerah perkotaan sebelum menyebar ke daerah sekitarnya. Denpasar dan Badung merupakan daerah yang tergolong maju di Bali dengan melihat Pendapatan Asli Daerahnya yang tinggi, hal tersebut tentunya juga ditunjang dengan pendapatan pajak yang diperoleh di daerah tersebut. Ini menandakan bahwa di daerah Denpasar dan Badung, banyak wajib pajak yang rutin melaporkan pajak sehingga kami anggap informasi terkait peraturan dan modernisasi penggunaan teknologi sudah disosialisasikan dengan baik. Terkait dengan hal ini kami melihat daerah lain di Bali juga memerlukan perhatian dalam penerapan dan sosialisasi sistem perpajakannya, salah satu daerah yang kami anggap perlu instensifikasi sistem perpajakan adalah Kabupaten Gianyar. Penelitian ini mengacu pada data yang diperoleh dari KPP Pratama Gianyar dalam mengangkat fenomena penelitian. Tingkat kepatuhan wajib pajak dari wajib pajak orang pribadi yang terdaftar di KPP Pratama Gianyar mengalami fluktuasi dari tahun ketahun dalam penelitian ini. Dari data yang diperoleh peneliti merasa angka kepatuhan wajib pajak orang pribadi di KPP Pratama Gianyar belum konsisten maka masih perlu dilakukan penelitian dengan variabel-variabel terkait. Peneliti merasa perlu melakukan penelitian terkait untuk mengetahui lebih jelas seberapa patuh wajib pajak di Kabupaten Gianyar, yang dimana pendapatan pajak tentu akan menopang tingkat pendapatan Nasional. Penelitian ini dilakukan di Kantor Pelayanan Pajak Pratama Gianyar karena setelah kami melihat penelitianpenelitian oleh peneliti sebelumnya sangat jarang kantor pajak di Gianyar 
digunakan sebagai objek penelitian. Tentu dengan minimnya informasi terkait penelitian ini kami ingin mengetahui bagaimana pengaruh sanksi perpajakan, penggunaan e-SPT, dan kualitas pelayanan fiskus pada kepatuhan wajib pajak orang pribadi yang terdaftar di Kantor Pelayanan Pajak Pratama Gianyar di Kabupaten Gianyar.

Tingkat kepatuhan pelaporan SPT tahunan WPOP di KPP Pratama Gianyar mengalami fluktuasi, apabila kita amati melalui Tabel 1.1 dimana dari tahun 2013 hingga 2016 tingkat kepatuhan WPOP menunjukkan tingkat persentase yang menurun. Hal tersebut juga menunjukkan bahwa tingkat kepatuhan WPOP di KPP Pratama Gianyar masih terbilang cukup rendah., bahkan di tahun 2016 tingkat kepatuhan WPOP menunjukkan persentase 49,58\% atau kurang dari setengah jumlah WPOP yang melaporkan SPT mereka. KPP Pratama Gianyar yang merupakan instansi yang memiliki kewajiban dalam memberikan pelayanan dengan ditunjang fasilitas yang memadai bagi segenap wajib pajak sehingga diharapkan senantiasa mengimbangi fasilitas yang tersedia dengan kualitas pelayanan yang baik demi memberi kenyamanan bagi para wajib pajak, sehingga dapat memicu respon positif dari para wajib pajak untuk lebih tepat waktu dalam melaporkan SPT mereka.

Penelitian mengenai pengujian tentang kepatuhan pajak pernah dilakukan diantaranya oleh Abdi (2017) dan Pranata (2015). Penelitian-penelitian tersebut mendapatkan hasil yang berbeda mengenai pengaruh antar satu variabel dengan variabel lainnya. Pada penelitian yang dilakukan oleh Abdi (2017) diperoleh hasil kepatuhan wajib pajak tidak dipengaruhi oleh sanksi yang diberikan, sedangkan 
hasil penelitian yang didapat oleh Pranata (2015) menyatakan bahwa sanksi perpajakan berpengaruh positif signifikan terhadap kepatuhan wajib pajak.

Berdasarkan latar belakang yang telah diuraikan di atas, peneliti ingin meneliti tentang "Pengaruh Sanksi Perpajakan, Penggunaan e-SPT, dan Kualitas Pelayanan Fiskus pada Kepatuhan Wajib Pajak Orang Pribadi yang Terdaftar di Kantor Pelayanan Pajak Pratama Gianyar”.

Rumusan masalah yang dapat diajukan yaitu: 1) Apakah sanksi perpajakan berpengaruh pada kepatuhan wajib pajak orang pribadi yang terdaftar di Kantor Pelayanan Pajak Pratama Gianyar?, 2) Apakah penggunanaan e-SPT berpengaruh pada Kepatuhan wajib pajak orang pribadi yang terdaftar di Kantor Pelayanan Pajak Pratama Gianyar?, 3) Apakah kualitas pelayanan fiskus berpengaruh pada kepatuhan wajib pajak orang pribadi yang terdaftar di Kantor Pelayanan Pajak Pratama Gianyar?.

Tujuan penelitian ini diharapkan agar Penelitian memberikan bukti empiris pengembangan teori atribusi dalam bidang ilmu akuntansi yang berkaitan dengan Pengaruh Sanksi Perpajakan, Penggunaan e-SPT, dan Kualitas Pelayanan Fiskus Pajak pada Kepatuhan Wajib Pajak. Selain itu, penelitian ini juga diharapkan agar dapat menjadi tambahan referensi bagi penelitian selanjutnya. Hasil dari penelitian ini dapat memberikan kontribusi pemikiran kepada pembaca khususnya bagi para Wajib Pajak agar memanfaatkan berbagai fasilitas yang tersedia yang mampu menunjang kemudahan dalam pelaporan SPT agar dapat meningkatkan kepatuhan terhadap pembayaran pajak tahunan 
Teori yang melandasi penelitian ini adalah teori atribusi. Teori atribusi dikemukakan oleh Harold Kelley (1972) pada awalnya merupakan teori yang ditemukan oleh Fritz Heider (1958) kemudian teori ini lebih disempurnakan lagi olehnya. Teori ini menjelaskan individu memiliki upaya untuk menjelaskan berbagai perilaku individu lain yang diamatinya, apakah perilaku tersebut disebabkan dari pihak eksternal maupun internal (Robbins dan Judge, 2008). Menurut Robbins dan Judge (2008), penentuan apakah perilaku disebabkan secara internal atau eksternal dipengaruhi tiga faktor berikut.

Faktor pertama yaitu kekhususan. Kekhususan menekankan pada sikap individu yang senantiasa berubah-ubah dalam berbagai situasi. Perilaku ini dianggap biasa maka dapat dijelaskan bahwa lingkungan internal lah yang menyebabkannya. Sebaliknya, apabila perilaku dianggap tidak biasa maka bisa disebakan secara eksternal. Faktor kedua ialah consensus. Konsensus merupakan kebalikan dari kekhususan dimana consensus ini menggambarkan sikap individu yang memberikan respon yang sama dalam menghadapi situasi yang sama. Penyebab sikap ini terlihat dari tinggi rendah tingkat konsensusnya. Faktor yang terakhir ialah konsistensi. Konsistensi mengacu pada respon yang sama dalam merespon untuk berbagai situasi. Perilaku dikatakan disebabkan faktor internal apabila perilaku tersebut semakin konsisten. Sebaliknya jika semakin tidak konsisten maka perilaku tersebut disebabkan secara eksternal.

Teori atribusi ini digunakana dalam penelitian ini karena relevan mampu menjelaskan berbagai faktor yang dapat memengaruhi kepatuhan wajib pajak. Sikap wajib pajak dalam menilai pajak dapat dikaitkan dengan bagaimana 
kepatuhan wajib pajak tersebut. persepsi individu ini dapat dipengaruhi oleh faktor internal maupun eksternal dalam proses penilaiannya (Jatmiko, 2006).

Teori belajar sosial dikenalkan oleh Albert Bandura, yang menekankan pada komponen kognitif melalui pikiran, pemahaman serta evaluasi. mana konsep dariteori ini menekankan pada komponen kognitif dari pikiran, pemahaman dan evaluasi. Menurut Bandura, sebagain besar orang belajar melalui pengalaman yang dialaminya atau dapat dikatakan mereka mencontoh model yang sudah ada. Albert Bandura mengemukakan bahwa seorang individu belajar banyak tentang perilaku melalui peniruan atau modeling, bahkan tanpa adanya penguat (reinforcement) sekalipun yang diterimanya. Proses belajar semacam ini disebut "observational learning" atau pembelajaran melalui pengamatan. Albert Bandura(1971), mengemukakan bahwa teori pembelajaran sosial membahas tentang (1) bagaimana perilaku kita dipengaruhi oleh lingkungan melalui penguat (reinforcement) dan observational learning, (2) cara pandang dan cara pikir yang kitamiliki terhadap informasi, (3) begitu pula sebaliknya, bagaimana perilaku kita mempengaruhi lingkungan kita dan menciptakan penguat (reinforcement) dan observational opportunity..

Adapun kerangka konseptual dalam penelitian ini menggambarkan pengaruh antar variabel dalam penelitian. Kerangka konseptual dalam penelitian ini disajikan pada gambar 1 sebagai berikut. 


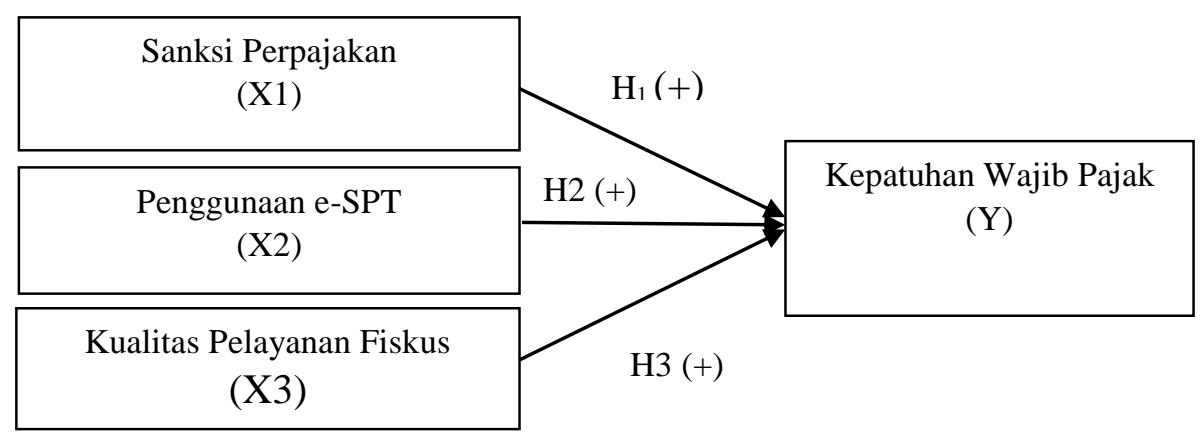

Gambar 1. Kerangka Konseptual

Bila mengacu pada konsep teori atribusi, maka sanksi pajak dikategorikan dalam penyebab eksternal dikarenakan terdapat pengaruh persepsi wajib pajak selama proses penilaian mengenai perilaku kepatuhan wajib pajak dalam melaksanakan kewajiban perpajakannya. Berdasarkan teori pembelajaran sosial, wajib pajak dapat belajar melalui proses pengalaman dan pengamatan dalam pemberian sanksi pajak oleh aparat pajak kepada wajib pajak yang melanggar norma perpajakan.

Sanksi dapat dikatakan sebagai hukuman kepada orang yang melanggar suatu atauran yang telah ditetapkan. Sanksi ini diperlukan untuk menekan angka pelanggaran terhadap peraturan perundang-undangan (Arum, 2012). Sanksi perpajakan merupakan jaminan agar wajib pajak senantiasa mematuhi perundangundangan perpajakan (Mardiasmo, 2011:59). Jika kewajiban pajak tidak ditaati maka sanksi pajak akan menunggu wajib pajak yang melanggar, ini merupakan konsekuensi hukum atas apa yang mereka lakukan. Penerapan ini tentunya bertujuan untuk menekan tingkat pelanggaran yang dilakukan wajib pajak agar mereka jera dan mau menaati semua norma perpajakan sehingga menciptakan kepatuhan wajib pajak dalam memenuhi kewajiban pajaknya. Wajib pajak 
diyakini akan patuh membayar apabila sanksi perpajakan yang diterapkan memberi efek merugikan yang lebih banyak (Jatmiko, 2006). Sehingga dapat dikatakan bahwa sanksi pajak akan berdampak pada tingkat kepatuhan wajib pajak. Hal ini juga didukung oleh berbagai penelitian yang pernah dilakukan oleh Jatmiko (2006), Muliari dan Setiawan (2010), dan Arum (2012) yang mendapatkan fakta bahwa sanksi pajak berpengaruh positif terhadap kepatuhan wajib pajak. Berdasarkan penjabaran diatas, maka dirumuskan hipotesis sebagai berikut.

$\mathrm{H}_{1}$ : Sanksi pajak berpengaruh positif terhadap kepatuhan wajib pajak.

Berdasarkan teori atribusi, penggunaan e-SPT ini dikategorikan dalam penyebab eksternal dikarenakan terdapat pengaruh persepsi wajib pajak dalam membuat peniklaian tentang perilaku kepatuhan wajib pajak dalam memenuhi kewajibannya. Berdasarkan teori pembelajaran sosial, wajib pajak dapat belajar melalui proses pengalaman dan pengamatan dalam penggunaan e-SPT karena dirasa memudahkan dalam membantu melaksanakan kewajiban perpajakannya. ESPT merupakan aplikasi pelaporan SPT tahunan yang diluncurkan oleh Direktorat Jenderal Pajak yang bertujuan untuk memudahkan para wajib pajak untuk menyetorkan SPT tahunan mereka. Dengan diluncurkannya aplikasi ini tentu diharapkan para wajib pajak tidak perlu menghabiskan waktu untuk datang ke kantor pajak dan mengantri di sana. Antrian panjang biasanya ditemui pada saatsaat akhir penyetoran atau pembayaran pajak. Sosialisasi terkait e-SPT ini sudah digalakkan oleh pemerintah kepada masyarakat agar dapat memanfaatkannya dengan baik. Aplikasi e-SPT diluncurkan aplikasi ini dari tahun 2014. Wajib 
pajak tidak perlu lagi mencetak banyak lembaran yang akan dilaporkan ke Kantor Pajak lagi karena hanya perlu mencetak hasil dari e-SPT pada saat melaporkan.Kemudahan ini tentunya dapat membuat wajib pajak lebih leluasa dan mudah dalam melaporakan SPT tahunan. Hal ini sejalan dengan penelitian yang dilakukan oleh Ira Prananti (2014) yang menemukan hasil pengaruh positif e-SPT terhadap kepatuhan wajib pajak. Berdasarkan penjabaran diatas, maka dirumuskan hipotesis sebagai berikut.

$\mathrm{H}_{2}$ : Penggunaan e-SPT berpengaruh positif pada kepatuhan wajib pajak.

Mengacu pada teori atribusi, kualitas pelayanan dikatakan sebagai penyebab eksternal karena hal ini dilakukan oleh apparat pajak sehingga dapat memengaruhi persepsi wajib pajak dalam bersikap. Berdasarkan teori pembelajaran sosial, wajib pajak dapat melakukan proses perhatian dan proses reproduksi motorik melalui pengamatan maupun pengalaman oleh aparat pajak dalam memberikanpelayanan kepada waib pajak. Aparat pajak yang memberikan kualitas pelayanan yang baik kepada wajib pajak berhubungan erat dengan wajib pajak dalam memenuhi kewajiban perpajakannya. Pelayanan yang berkualitas yaitu pelayanan yang diberikan secara maksimal dan memperoleh hasil kepuasan yang baik oleh wajib pajak dalam batas memenuhi standar pelayanan yang dapat dipertanggungjawabkan serta harus dilakukan secara terus-menerus (Supadmi, 2009). Pelayanan tidak berkualitas bila apparat pajak tidak dapat memenuhi harapan wajib pajak. Sehingga semakin baik kualitas pelayana yang diberikan oleh aparatur pajak maka akan mampu memberikan kepuasan terhadap wajib pajak sehingga mereka cenderung akan mematuhi kewajiban perpajakannya. 
Sebalikanya, jika kualitas yang diberikan buruk dan tidak maksimal maka akan semakin tidak patuh pula wajib pajak dalam memenuhi kewajiban pajaknya. Penelitian yang dilakukan Arum (2012) dan Fuadi (2013) mendukung hal ini dimana mereka menemukan hasil bahwa kualitas pelayanan sejalan dengan kepatuhan wajib pajak. Berdasarkan penjabaran diatas, maka dapat dirumuskan hipotesis sebagai berikut.

$\mathrm{H}_{3}$ : Kualitas pelayanan fiskus berpengaruh positif pada kepatuhan wajib pajak.

\section{METODE PENELITIAN}

Penelitian ini menggunakan pendekatan kuantitatif dengan tingkat eksplanasi penelitian berbentuk penelitian asosiatif dengan tipe kausalitas adalah penelitian yang menjelaskan pengaruh variabel independen terhadap variabel dependen (Sugiyono, 2018:55). Ada pun lokasi penelitian ini dilakukan pada wajib pajak yang terdaftar di Kantor Pajak Pratama Kabupaten Gianyar tahun 2014-2017. Obyek dalam penelitian ini adalah kepatuhan wajib pajak orang pribadi yang terdaftar di Kantor Pelayanan Pajak Pratama Gianyar pada tahun 2014-2017. Variabel terikat dalam penelitian ini adalah kepatuhan wajib pajak yang dilambangkan dengan Y. Variabel bebas dalam penelitian ini adalah sanksi perpajakan, penggunaan e-SPT, dan kualitas pelayanan fiskus yang berturut-turut dilambangkan dengan $\mathrm{X}_{1}, \mathrm{X}_{2}$, dan $\mathrm{X}_{3}$

Sanksi perpajakan merupakan jaminan agar wajib pajak senantiasa mematuhi perundang-undangan perpajakan, serta merupakan alat yang digunakan untuk mencegah serta menurunkan tingkat ketidakpatuhan wajib pajak (Mardiasmo, 2016:62). E-SPT adalah aplikasi yang dibuat oleh Direktorat 
Jenderal Pajakuntuk digunakan oleh ajib pajak dalam membuat SPT dengan lebih mudah dan tidak menggunakan banyak banyak kertas. Pelayanan yang berkualitas adalah pelayanan yang dapat memberikan kepuasan kepada Wajib Pajak dantetap dalam batas memenuhi standar pelayanan yang dapat dipertangungjawabkan serta harus dilakukan secara terus-menerus (Supadmi, 2009). Kepatuhan wajib pajak adalah pemenuhan kewajiban perpajakan sesuai dengan ketentuan perundangan yang berlaku yang dilakukan oleh wajib pajak.

Populasi dalam penelitian ini adalah jumlah seluruh wajib pajak orang pribadi efektif yang menggunakan e-SPT yang terdaftar pada Kantor Pelayanan Pajak Pratama Gianyar sejumlah 107 orang WPOP. Untuk menentukan ukuran sampel wajib pajak orang pribadi efektif di Kantor Pelayanan Pajak Pratama Gianyar digunakan dengan rumus Slovin, maka diperolehlah jumlah sampel sebanyak 52 responden yang menggunakan e-SPT. Jumlah populasi sebanyak 107 orang WPOP disusutkan menjadi 52 orang WPOP sebagai sampel ini bertujuan agar peneliti lebih efisien dalam mendapatkan data kuisioner dari jumlah sampel yang telah ditentukan. Metode penentuan sampel menggunakan metode accidental sampling, dan Pengumpulan data primer dilakukan dengan metode survei menggunakan media angket (kuesioner).

Pada penelitian ini mempergunakan metode pengumpulan data observasi nonpartisipan. Dilakukan Uji Validitas dan Reliabilitas, Uji Statistik Deskriptif, Uji Kelayakan Model Regresi hingga Uji analisis Regresi Linier berganda yang menghasilkan persamaan sebagai berikut. 
$\mathrm{Y}=\alpha+\beta 1 \mathrm{X} 1+\beta 2 \mathrm{X} 2+\beta 3 \mathrm{X} 3+\mathrm{e}$

Keterangan:

$\mathrm{Y}=$ kepatuhan wajib pajak

$\alpha=$ konstanta

$\beta 1=$ variabel sanksi perpajakan

$\beta 2=$ variabel penggunaan e-SPT

$\beta 3=$ variabel kualitas pelayanan fiskus

$\mathrm{e}=$ error

\section{HASIL DAN PEMBAHASAN}

Dalam penyebaran kuisioner peneliti menyerahkan kuisioner kepada WPOP yang melaporkan SPTnya di loket 7 yang diamana loket 7 merupakan loket khusus yang melayani pelaporan SPT dengan sistem e-SPT ataupun melayani konsultasi mengenai e-SPT. Ringkasan pengiriman dan pengembalian kuesioner dapat dilihat pada tabel 1.

Tabel 1.

Distribusi Kuesioner

\begin{tabular}{lcc}
\hline \multicolumn{1}{c}{ Item } & Jumlah & Presentase (\%) \\
\hline Kuesioner yang dibagikan & 52 & $100 \%$ \\
Kuesioner yang tidak diisi & 0 & $0 \%$ \\
Kuesioner yang tidak diisi dengan lengkap & 0 & $0 \%$ \\
Kuesioner yang dapat diolah & 52 & $100 \%$ \\
\hline Tingkat Pengembalian Kuesioner (respon rate) & $: 52 / 52 \times 100 \%=100 \%$ & \\
Kuesioner yang digunakan (useable respon rate) & $: 52 / 52 \times 100 \%=100 \%$ & \\
\hline
\end{tabular}

Sumber: Data diolah, 2018

Statistik deskriptif berhubungan dengan pengumpulan dan peringkat data yang menggambarkan karakteristik dari masing-masing variabel yang digunakan dalam penelitian ini. Analisis ini berguna untuk menjelaskan karakteristik dari variabel penelitian diantaranya : nilai rata-rata (mean), nilai ekstrim yaitu nilai minimum dan nilai maksimum, standar deviasi serta $\mathrm{N}$ yang merupakan jumlah responden 
dalam penelitian ini. Hasil dari deskriptif tersebut dapat dilihat pada Tabel 2. berikut.

Tabel 2.

Statistik Deskripstif Variabel-Variabel Penelitian

\begin{tabular}{llllll}
\hline & N & Minimum & Maximum & Mean & Std. Deviation \\
\hline Sanksi papjak $\left(\mathrm{X}_{1}\right)$ & 52 & 1,50 & 5,00 & 4,0545 & 0,68339 \\
Penggunan $\left(\mathrm{X}_{2}\right)$ & 52 & 2,83 & 5,00 & 3,9119 & 0,51089 \\
Kualitas Pelayanan Fiskus $\left(\mathrm{X}_{3}\right)$ & 52 & 2,83 & 5,00 & 3,9872 & 0,43711 \\
Kepatuhan Wajib Pajak (Y) & 52 & 2,71 & 5,00 & 3,9945 & 0,51154 \\
\hline
\end{tabular}

Sumber: Data diolah, 2018

Nilai terendah (minimum) untuk variabel kualitas pelayanan sebesar 1,50 nilai tertinggi (maximum) sebesar 5,00 dan nilai rata-rata (mean) sebesar 4,05 hal ini mengidentifikasikan bahwa sanksi perpajakan dapat meningkatkan kepatuhan wajib pajak. Nilai standar deviasi sebesar 0,68 ini berarti bahwa standar penyimpangan data terhadap nilai rata-rata adalah 0,68 .

Nilai terendah (minimum) untuk variabel kualitas pelayanan sebesar 2,83 nilai tertinggi (maximum) sebesar 5,00 dan nilai rata-rata (mean) sebesar 3,91 hal ini mengidentifikasikan bahwa penggunaan e-SPT dapat meningkatkan kepatuhan wajib pajak. Nilai standar deviasi sebesar 0,51 ini berarti bahwa standar penyimpangan data terhadap nilai rata-rata adalah 0,51 .

Nilai terendah (minimum) untuk variabel kualitas pelayanan sebesar 2,83 nilai tertinggi (maximum) sebesar 5,00 dan nilai rata-rata (mean) sebesar 3,98 hal ini mengidentifikasikan bahwa sanksi perpajakan dapat meningkatkan kepatuhan wajib pajak. Nilai standar deviasi sebesar 0,43 ini berarti bahwa standar penyimpangan data terhadap nilai rata-rata adalah 0,43 . 
Nilai terendah (minimum) untuk variabel kepatuhan wajib pajak sebesar 2,71, nilai tertinggi (maximum) sebesar 5,00 dan nilai rata-rata (mean) sebesar 3,99. Nilai standar deviasi variabel kepatuhan wajib pajak sebesar 0,51 ini berarti bahwa perbedaan nilai variabel kepatuhan wajib pajak yang di teliti terhadap nilai rata-rata sebesar 0,51 .

Selanjutnya dilakukan Uji Validitas dan Reliabilitas. Valid berarti variabel tersebut dapat digunakan untuk mengukur apa yang seharusnya diukur. Hal ini berarti mengukur sejauh mana ketepatan pertanyaan yang digunakan dalam kuesioner untuk mengukur variabel yang akan diteliti. Suatu instrumen akan dikatakan valid apabila skor faktor dengan skor total dan bila kolerasi tiap faktor tersebut pofitif 0,30 ke atas (Sugiyono, 2018 : 134). Hasil uji menunjukkan bahwa variabel sanksi perpajakan, penggunaan e-SPT, dan kualitas pelayanan fiskus memiliki pearson correlation lebih dari 0,30. Sehingga pernyataan yang digunakan dalam kuesioner penelitian ini telah memenuhi standar valid sehingga layak digunakan sebagai penelitian. Kemudian hasil uji reliabilitas menunjukan bahwa nilai cronbach's alpha masing-masing variabel yaitu sanksi perpajakan, penggunaan e-SPT, kualitas pelayanan fiskus, dan kepatuhan wajib pajak memiliki nilai lebih besar dari 0,70. Hal ini menunjukkan bahwa semua pernyataan dalam kuesioner penelitian ini reliabel dan dapat diteliti lebih lanjut. Hal ini berarti apabila dilakukan pengukuran lebih dari satu kali terhadap gejala yang sama maka pengukuran tersebut akan memberikan hasil yang konsisten.

Kemudian dilakukan uji normalitas. Pengujian normalitas data penelitian ini menggunakan metode Kolmogorov-Smirnov. Kriteria yang digunakan dalam 
tes ini adalah dengan membandingkan antara tingkat signifikansi yang didapat dengan tingkat alpha yang digunakan yaitu 0,05 , dimana data tersebut dikatakan berdistribusi normal bila sig > alpha (Ghozali, 2016:30). Hasil Uji menunjukkan bahwa nilai signifikansi persamaan sebesar 0,200 lebih besar dari 0,05. Hal ini berarti data dalam penelitian ini berdistribusi normal.

Uji multikolinearitas bertujuan untuk menguji apakah pada model regresi ditemukan adanya korelasi antar variabel bebas. Multikolinearitas dapat dilihat dari nilai tolerance dan variance inflation factor (VIF), suatu model regresi yang bebas dari masalah multikolinearitas apabila mempunyai nilai toleransi $\geq 0,10$ dan nilai VIF $\leq 10$. Dari hasil uji didapatkan hasil nilai tolerance pada masing-masing variabel bernilai diatas $10 \%(0,10)$ dan nilai VIF dibawah 10 . Sehingga dapat dikatakan tidak terjadi multikolinieritas.

Heteroskedastisitas tidak terjadi apabila bila nila t hitung lebih kecil dari t tabel dan bernilai signifikan jika lebih besar dari 0,05. Model regresi yang baik yakni apabila tidak terjadi heteroskedastisitas. Hasil uji diketahui semua variabel bebas pada model regresi tersebut memiliki nilai signifikansi lebih besar dari 0,05. Sehingga tidak terjadi gejala heteroskedastisitas pada model penelitian ini.

Selanjutnya dilakukan uji analisis regresi linear berganda serta uji kelayakn model. Berdasarkan hasil pengolahan data dengan bantuan SPSS, maka didapatkan hasil seperti dibawah ini. 
Tabel 3.

Rekapitulasi Hasil Analisis Regresi Linier Berganda

\begin{tabular}{lccccc}
\hline \multicolumn{1}{c}{ Variabel } & \multicolumn{2}{c}{$\begin{array}{c}\text { Unstandardized } \\
\text { Coefficients }\end{array}$} & $\begin{array}{c}\text { Standardized } \\
\text { Coefficients }\end{array}$ & t & Signifikansi \\
& B & Std. Eror & Beta & \\
\hline Constant) & 2,920 & 3,999 & & 0,730 & 0,469 \\
Sanksi Perpajakan & 0,217 & 0,096 & 0,248 & 2,251 & 0,029 \\
Penggunaan e-SPT & 0,159 & 0,074 & 0,272 & 2,136 & 0,038 \\
Kualitas Pelayanan & 0,171 & 0,059 & 0,377 & 2,888 & 0,006 \\
Fiskus & & & & & \\
\hline Adjusted $R$ Square & & & 0,418 & \\
F Hitung & & & 0,000 & \\
Signifikansi F & & & & \\
\hline
\end{tabular}

Sumber: Data diolah, 2018

Berdasarkan hasil diatas, maka diperoleh model regresi sebagai berikut:

$$
\mathrm{Y}=8,128+0,064 \mathrm{X}_{1}+0,352 \mathrm{X}_{2}-0,230 \mathrm{X}_{3}+\mathrm{e}
$$

Nilai konstanta sebesar 2,920 menunjukkan apabila sanksi perpajakan $\left(\mathrm{X}_{1}\right)$, penggunaan e-SPT $\left(\mathrm{X}_{2}\right)$, dan kualitas pelayanan fiskus $\left(\mathrm{X}_{3}\right)$ sebesar nol, maka kepatuhan wajib pajak (Y) meningkat sebesar 2,920. Hal ini menunjukkan bahwa wajib pajak orang pribadi di Kantor Pelayanan Pajak Pratama Gianyar sudah patuh dalam melaksanakan kewajiban perpajakannya. Nilai Koefisien Regresi variabel sanksi perpajakan sebesar 0,217. Hal ini bermakna bahwa sanksi perpajakan semakin meningkat maka kepatuhan wajib pajak dalam membayar pajak semakin meningkat Nilai Koefisien Regresi variabel penggunaan e-SPT sebesar 0,159. Hal ini bermakna bahwa penggunaan e-SPT semakin meningkat maka kepatuhan wajib pajak dalam membayar pajak semakin meningkat. Nilai Koefisien variabel kualitas pelayanan fiskus sebesar 0,171 . Hal ini bermakna bahwa kualitas pelayanan fiskus semakin meningkat maka kepatuhan wajib pajak dalam membayar pajak semakin meningkat. 
Koefisien determinasi (R2) pada hakikatnya mengukur seberapa jauh kemampuan model penelitian menerangkan variasi variabel independen. Hasil analisis menunjukkan nilai sebesar 0,418 . Ini berarti perubahan yang terjadi pada kepatuhan wajib pajak orang pribadi di Kantor Pelayanan Pajak Pratama Gianyar dapat dijelaskan oleh Sanksi Perpajakan (X1), penggunaan e-SPT (X2), dan kualitas pelayan fiskus (X3) sebesar 41,8 persen, sedangkan 58,2 persen sisanya dijelaskan oleh faktor lain yang tidak diuji dalam penelitian ini.

Berdasarkan hasil regresi diatas (Tabel 3.), siginifikansi F sebesar 0,000< 0,05 maka variabel independen berpengaruh serempak (simultan) terhadap variabel dependen. Hal ini berarti seluruh variabel independen (sanksi perpajakan, penggunaan e-SPT, dan kualitas pelayanan fiskus) dapat memprediksi atau menjelaskan fenomena kepatuhan wajib pajak orang pribadi di Kantor Pelayanan Pajak Pratama Gianyar, sehingga dapat disimpulkan bahwa model dalam penelitian ini dikatakan layak untuk diteliti.

Berdasarkan hasil perhitungan menggunakan Uji Regresi Linier Berganda pada Tabel 3. diketahui bahwa nilai $\beta 1$ adalah 0,217 dan signifikansi nilai $t$ sebesar 0,029 dimana angka tersebut lebih kecil dari nilai $\alpha$ yaitu 0,05. Artinya hipotesis pertama bahwa sanksi perpajakan berpengaruh positif pada kepatuhan wajib pajak orang pribadi di Kantor Pelayanan Pajak Pratama Gianyar diterima. Semakin meningkat sanksi perpajakan maka kepatuhan wajib pajak orang pribadi dalam membayar kewajiban perpajakkannya semakin meningkat.

Hal ini sesuai dengan konsep teori atribusi, dimana sanksi pajak dikategorikan dalam penyebab eksternal dikarenakan terdapat pengaruh persepsi 
wajib pajak selama proses penilaian mengenai perilaku kepatuhan wajib pajak dalam melaksanakan kewajiban perpajakannya. Berdasarkan teori pembelajaran sosial, wajib pajakdapat belajar melalui proses pengalaman dan pengamatan dalam pemberian sanksi pajak oleh aparat pajak kepada wajib pajak yang melanggar norma perpajakan.

Sanksi dapat dikatakan sebagai hukuman kepada orang yang melanggar suatu atauran yang telah ditetapkan. Sanksi ini diperlukan untuk menekan angka pelanggaran terhadap peraturan perundang-undangan (Arum, 2012). Sanksi perpajakan merupakan jaminan agar wajib pajak senantiasa mematuhi perundangundangan perpajakan (Mardiasmo, 2011:59). Hasil ini juga sesuai dengan penelitian sebelumnya yang dilakukan oleh Jatmiko (2006), Muliari dan Setiawan (2011), dan Arum (2012) yang menunjukkan bahwa sanksi pajak berpengaruh positif terhadap kepatuhan wajib pajak.

Berdasarkan hasil perhitungan menggunakan Uji Regresi Linier Berganda pada Tabel 43. diketahui bahwa nilai $\beta 2$ adalah 0,159 dan signifikansi nilai $t$ sebesar 0,038 yang berarti angka tersebut lebih kecil dari nilai $\alpha$ yaitu 0,05 . Artinya hipotesis kedua yang menyatakan bahwa penggunaan e-SPT berpengaruh positif pada kepatuhan wajib pajak orang pribadi di Kantor Pelayanan Pajak Pratama Gianyar diterima. Semakin meningkat penggunaan e-SPT maka kepatuhan wajib pajak orang pribadi dalam membayar kewajiban perpajakkannya semakin meningkat. Berdasarkan teori atribusi, penggunaan e-SPT termasuk dalam penyebab eksternal karena adanya pengaruh persepsi wajib pajak dalam membuat penilaian mengenai perilaku kepatuhan wajib pajak dalam 
melaksanakan kewajiban perpajakan. Berdasarkan teori pembelajaran sosial, wajib pajak dapat belajar melalui proses pengalaman dan pengamatan dalam penggunaan e-SPT karena dirasa memudahkan dalam membantu melaksanakan kewajiban perpajakannya. Hasil ini sejalan dengan penelitian yang dilakukan oleh Ira Prananti (2014) yang menyatakan bahwa e-SPT berpengaruh positif secara signifikan pada kepatuhan wajib pajak.

Berdasarkan hasil perhitungan menggunakan Uji Regresi Linier Berganda pada Tabel 4.8 diketahui bahwa nilai $\beta 3$ adalah 0,171 dan signifikansi nilai $\mathrm{t}$ sebesar 0,006 yang berarti angka tersebut lebih kecil dari nilai $\alpha$ yaitu 0,05 . Artinya hipotesis ketiga yang menyatakan bahwa kualitas pelayanan fiskus berpengaruh positif pada kepatuhan wajib pajak orang pribadi di Kantor Pelayanan Pajak Pratama Gianyar diterima. Semakin meningkat kualitas pelayanan fiskus maka kepatuhan wajib pajak orang pribadi dalam membayar kewajiban perpajakkannya semakin meningkat. Mengacu pada teori atribusi, kualitas pelayanan dikatakan sebagai penyebab eksternal karena hal ini dilakukan oleh apparat pajak sehingga dapat memengaruhi persepsi wajib pajak dalam bersikap. Berdasarkan teori pembelajaran sosial, wajib pajak dapat melakukan proses perhatian dan proses reproduksi motorik melalui pengamatan maupun pengalaman oleh aparat pajak dalam memberikanpelayanan kepada waib pajak. Sehingga semakin baik kualitas pelayana yang diberikan oleh aparatur pajak maka akan mampu memberikan kepuasan terhadap wajib pajak sehingga mereka cenderung akan mematuhi kewajiban perpajakannya. Sebalikanya, jika kualitas yang diberikan buruk dan tidak maksimal maka akan semakin tidak patuh pula 
wajib pajak dalam memenuhi kewajiban pajaknya. Hal ini didukung penelitian sebelumnya yang dilakukan oleh penelitian Arum (2012) dan Fuadi (2013) dimana kualitas pelayanan fiskus berpengaruh positif terhadap kepatuhan wajib pajak.

\section{SIMPULAN}

Kesimpulan dari penelitian ini yaitu: 1) Sanksi perpajakan berpengaruh positif pada kepatuhan wajib orang pribadi yang terdaftar di Kantor Pelayanan Pajak Pratama Gianyar. Hal ini menunjukkan bahwa semakin meningkat sanksi perpajakan yang diberikan maka semakin meningkatkan kepatuhan wajib pajak orang pribadi dalam membayar kewajiban pajaknya; 2) Penggunaan e-SPT berpengaruh positif pada kepatuhan wajib orang pribadi yang terdaftar di Kantor Pelayanan Pajak Pratama Gianyar. Hal ini menunjukkan bahwa semakin meningkatnya penggunaan e-SPT yang dilakukan oleh Wajib Pajak maka semakin meningkatkan kepatuhan wajib pajak orang pribadi dalam membayar kewajiban pajaknya; 3) Kualitas pelayanan fiskus berpengaruh positif pada kepatuhan wajib pajak orang pribadi yang terdaftar di Kantor Pelayanan Pajak Pratama Gianyar. Hal ini menunjukkan bahwa semakin meningkat kualitas pelayanan fiskus maka semakin meningkatkan kepatuhan wajib pajak orang pribadi dalam membayar kewajiban pajaknya.

Adapun beberapa hal yang dapat disarankan sesuai dengan hasil pembahasan hingga kesimpulan yang disajikan pada penelitian ini meliputi: 1) Sanksi perpajakan yang diberikan sudah cukup efektif dalam membuat para wajib pajak lebih menyadari bahwa apabila terkena sanksi perpajakan akan sangat merugikan bagi wajib pajak itu sendiri. Hal yang perlu dilakuakan sebagai langkah penegasan 
pengenaan sanksi perpajakan guna meningkatkan kepatuhan wajib pajak adalah sosialisasi lebih lanjut mengenai sanksi-sanksi perpajakan oleh para petugas pajak. 2) Penggunaan e-SPT dapat memudahkan para wajib pajak dalam melaksanakan kewajiban pajaknya, hal yang perlu dilakukan oleh para petugas pajak dalam hal ini adalah menjelaskan kepada para wajib pajak tentang kemudahan pelaporan pajak dengan menggunakan e-SPT itu sendiri. Apabila para wajib pajak memahami dengan baik cara menggunakan e-SPT dan dirasa memudahkan dalam mengisi SPT tahunan dari kewajiban pajak mereka maka tingkat kepatuhan wajib pajak akan mengalami peningkatan; 3). Kualitas pelayanan fiskus yang diberikan oleh para fiskus pajak sudah sangat baik ditinjau dari hasil penelitian ini, akan lebih baik lagi apabila kualitas pelayanan dari para fiskus pajak selalu mengalami peningkatanan, karena apabila para wajib pajak merasa mendapatkan pelayanan yang baik, merasa nyaman dengan suasana pelaporan pajaknya mereka pun akan lebih patuh dengan kewajiban pajaknya hal ini dapat menumbuhkan rasa kesadaran para wajib pajak dalam melaksanakan kewajiban pajaknya karena merasa tidak terbebani dengan adaya bantuan yang maksinal dari para fiskus pajak; serta 4) Bagi para wajib pajak khususnya wajib pajak orang pribadi agar lebih meningkatkan kepatuhan pajaknya karena hal tersebut dapat membantu meningkatkan pendapatan nasional. Wajib pajak diharapkan lebih aktif untuk mencari tahu mengenai peraturan perpajakan khususnya yang menyangkut tentang pembayaran pajak orang pribadi. 


\section{REFERENSI}

Abdi Rezan. (2017). Pengaruh Sanksi Pajak, Kualitas Pelayanan dan Penerapan Sistem E-Filling terhadap Kepatuhan Wajib Pajak Orang Pribadi (Studi Empiris Wajib Pajak Orang Pribadi yang Terdaftar di KPP Pratama1 Padang). E-Journal Universitas Negeri Padang, 10(5), p:14-15.

Alabede James, Todd Cherry, Michael Jones dan Michael Mckee. (2011). "Tax Payer Information Assistance Services and Tax Compliance Behavior". Tulane Economics Working Paper Series.

Andreoni J., Erard, B., \& Feinstein, J. (1998). Tax Compliance. Journal of Economic Literature, (36): pp. 818-819.

Arum Harjanti. (2012). "Pengaruh Kesadaran Wajib Pajak, Pelayanan Fiskus, dan Sanksi Pajak Terhadap Kepatuhan Wajib Pajak Orang Pribadi Yang Melakukan Kegiatan Usaha Dan Pekerjaan Bebas (Studi di Wilayah KPP Pratama Cilacap)". Diponegoro Journal Of Accounting, 01(1).

Bandua A. (1971). Social Learning Theory. New York: General Learning Press.

Barr N.A., James, S.R., \& Prest, A.R. (1977). Self-Assessment for Income Tax. London,Heinemann.

Bernasconi M. (1998) „Tax evasion and orders of risk aversion, “ Journal of Public Economics, 67: pp. 123-134.

Carlos Pinho,Jose., Maria de Lurdes Martins., Isabel Macedo, (2011). "The effect of online service quality factors on internet usage: The web delivery system of the taxation department", International Journal of Quality \& Reliability Management, 28(7): pp.706 - 722

Chattopadhayay, S. and Arindam Das Gupta. (2002). "The Personal Income Tax in India: Compliance Cost and Compliance Behavior of Taxpayers". National Institute of Public Finance and Policy. New Delhi

Cho J., Linn, S.C. \& Nakibullah, A. (1996). “Tax evasion with psychic costs and penalty renegotiation”. Southern Economic Journal, 63: pp. 172 - 191.

Cuccia, A. D. (1994). "The effects of increased sanctions on paid tax preparers; integrating economic and psychological factors". Journal of the American Taxation Association, 16(1): pp. 41-66. 
Direktorat Jendral Pajak. (2007). Undang-Undang Republik Indonesia Nomer 28 Tahun 2007 tentang Perubahan Ketiga Atas Undang-Undang Republik Indonesia Nomer 6 Tahun 1983 tentang Ketentuan Umum dan Tata Cara Perpajakan. Jakarta.

Devano Sony, Siti Kurnia Rahayu. (2006). Perpajakan Konsep, Teori dan Isu. Jakarta: Prinadi Media Group.

Direktorat Jendral Pajak. (2009). Surat Edaran Direktorat Jendral Pajak No. SE89/PJ/2009 tentang Kriteria Wajib Pajak Efektif dan Wajib Pajak Non Efektif. Jakarta.

Doran Michael. (2009). "Tax Pinalties and Tax Compliance, Harvard Journal on Legislation. 46: p: 111-161. www.ssrn.com.

Erard B., \& Feinstein, J. S. (1994b). "Honesty and evasion in the tax compliance game". Rand Journal of Economics, 25(1): pp. 1-20.

Falkinger, J., \& Walther, W. (1991). "Rewards versus penalties: on a new policy against tax evasion”. Public Finance Quarterly, 19(1): pp. 67-79.

Fuadi Oentara dan Yenni Mangoting. (2013). Pengaruh Kualitas Pelayanan Petugas Pajak, Sanksi Perpajakan dan Biaya Kepatuhan Pajak Terhadap

Kepatuhan Wajib Pajak UMKM. Tax and Accounting Review,Vol 1.No 1.2013

Ghozali Imam. (2013). Aplikasi Analisis Multivariate dengan Program IBM SPSS 21. Semarang: Badan Penerbit-Undip.

James, S., \& Wallschutzky, I. (1995). "Considerations Concerning the Design of an Appropriate System of Tax Rulings”. Revenue Law Journal, 175.

Mardiasmo. (2016). Perpajakan. Edisi Terbaru 2016. Yogyakarta: Andi.

Mulyodiwarno Nuryadi. "Catatan Tentang Kebijakan Sanksi Perpajakan Sejak Undang-undang KUP 2007”. Inside Tax, Jakarta, 2007.

Ngadiman; Daniel Huslin. (2015). Pengaruh Sunset Policy, Tax Amnesty, dan Sanksi Pajak terhadap Kepatuhan Wajib Pajak (Studi Empiris di Kantor Pelayanan Pratama Jakarta Kembangan), Jurnal Akuntansi/Volume XIX, No. 02, Mei 2015: 225-241. 
Ni Ketut Muliari dan Putu Ery Setiawan. (2011). Pengaruh Persepsi Tentang Sanksi Perpajakan dan Kesadaran Wajib Pajak Pada Kepatuhan Pelaporan Wajib Pajak Orang Pribadi Di Kantor Pelayanan Pajak Pratama Depansar Timur. Jurnal Akuntansi dan Bisnis, 2.

Ni Luh Supadmi. (2009). Meningkatkan Kepatuhan Wajib Pajak Melalui Kualitas Pelayanan. Audit Jurnal Akuntansi dan Bisnis, 04(2): h:214-219, Denpasar: Fakultas Ekonomi Universitas Udayana.

Prananti, Ni Putu Ira \& Ni Ketut Rasmini. (2014). Pengaruh Modernisasi Administrasi Perpajakan, Pelayanan Fiskus dan Penggunaan e-SPT pada Kepatuhan Pajak. E-Jurnal Akuntansi Universitas Udayana, 6

Pranata Aditya. (2015). Pengaruh Sanksi Perpajakan, Kualitas Pelayanan dan Kewajiban Moral pada Kepatuhan Wajib Pajak. E-Jurnal Akuntansi Universitas Udayana, 10(2), p: 456-473.

Rahayu Sri. (2009). Pengaruh Modernisasi Ssitem Administrasi Perpajakan terhadap Kepatuhan Wajib Pajak (Survei atas Wajib Pajak Badan pada KPP Pratama Bandung "X”). Jurnal Akuntansi 1(2).

Resmi Siti. (2008). Perpajakan, Teori dan Kasus. Edisi Keempat. Jakarta: Salemba Empat.

Robbins Stephen P. dan Timothy A. Judge. (2008). Perilaku Organisasi Edisi ke12, Jakarta: Salemba Empat.

Rohmawati Alifa Nur. (2012) Pengaruh Kesadaran, Penyuluhan, Pelayanan, Dan Sanksi Perpajakan Pada Kepatuhan Wajib Pajak Orang Pribadi. E-Jurnal Akuntansi Universitas Udayana, 1(2).

Rosdiana Haula dan Irianto, Slamet Edi. (2011). Panduan Lengkap Tata Cara Perpajakan di Indonesia. Jakarta: Visi Media

Rustiyaningsih, Sri. (2011). Faktor-Faktor yang Mempengaruhi Kepatuhan Wajib Pajak. Widya Warta. 35(2): h:44-54.

Salsalina Ita. Lingga. (2012). Pengaruh Penerapan E-SPT Terhadap Efisiensi Pemrosesan Data Perpajakan: Survey Terhadap Pengusaha Kena Pajak pada KPP Pratama X Bandung. Jurnal Akuntansi 04(2), Universitas Kristen Maranatha 
Smith, K.W. \& Kinsey, K.A. (1987). "Understanding taxpayer behaviour: a conceptual framework with implications for research". Law and Society Review, Vol. 21.

Sugiyono. (2018). Metode Penelitian Kuantitatif, kualitatif, dan $R \& D$. Cetakan ke-27. Bandung: Alfabeta

Torgler Benno and Friedrich Schneider. (2009). "The Impact of Tax Morale and Institutional Quality on The Shadow Economy". Journal of Economic Psychology,30(2): p:228-245

Qing Hong. (2006). "Service Quality Perceptions in Fast Food Restaurants in China". Journal of Finance and Management in Public Service, 02(2): p:2026. 